\title{
TRUSSES OF TENSEGRITY TYPE IN A CONCEPT OF TRAIN STATION RENOVATION IN ŻARY
}

\author{
Paulina LECHOCKA ${ }^{1}$ \\ University of Zielona Gora, Institute of Building Engineering, Zielona Góra, Poland
}

\begin{abstract}
The first railway station in Żary was built in 1843 in Germany. After the Second World War and years of socialism in Poland the meaning of railway decreased and its technical condition deteriorated. Now the building needs renovation and change of function. Tensegrity structures may be useful in renovation of platforms shelter. They are strut and tie construction, in which there is self-stabilization between compressed and tensioned elements. Conception of new platform shelter is based on exemplary tensegrity module consist of three struts and nine cables (called „Simplex”). Tensegrity would make railway station more modern, but not cover its original elevation.
\end{abstract}

Keywords: $\quad$ tensegrity, railway station, Żary

\section{HISTORICAL CHARACTER AND SIGNIFICANCE OF TRAIN STATION IN ŻARY}

The history of train station in Żary dates back to 1843, when in pre-war Germany, the Society of Railway Lower Silesia-Marchijska was established [1]. The company was to build a railway line from Wrocław to Frankfurt an der Oder, leading, among others, via Żary. Three years later there was opened the first railway station in the city's history and officially launched Berlin-Wrocław arterial road. Even then, the building is not just about waiting room, but also a restaurant (Fig. 1).

\footnotetext{
${ }^{1}$ Corresponding author: University of Zielona Gora, Institute of Building Engineering, Szafrana str 1, 65-516 Zielona Gora, Poland, e-mail: paulina.lechocka@ gmail.com, tel. +48683282271
} 


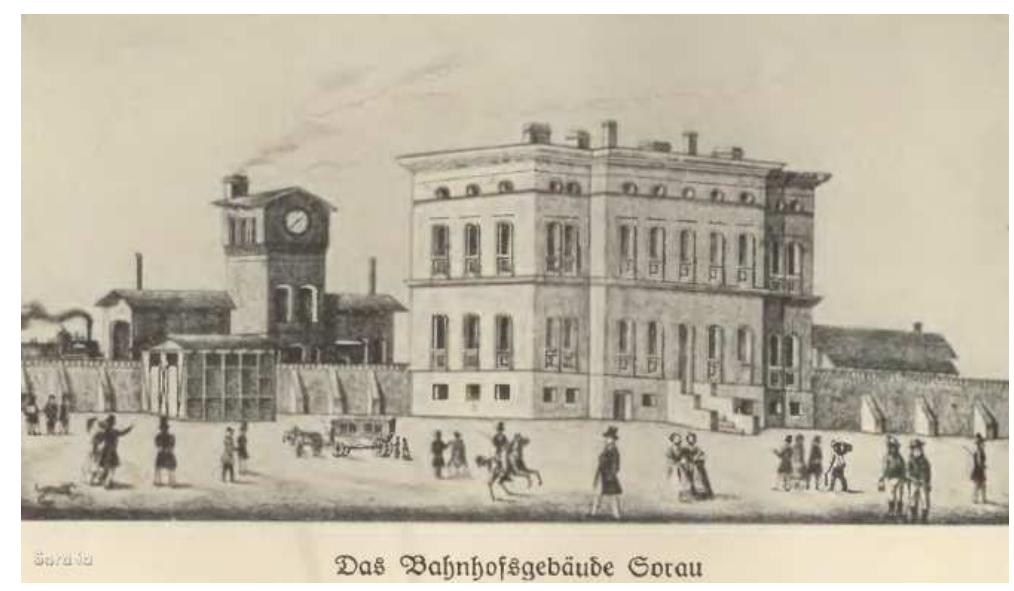

Fig. 1. The first railway station in Żary in 1846 [www.zary.fotopolska.eu]

Development of railways progressed. In 1877 , to the city already led three railway lines; it became necessary to create one common train station for all routes. There were built two further platforms, built on the ramparts, as well as the underground passage, connecting them with the building of the station. The area in front of building was lowered, creating a large square, as well as the streets around the station were rebuilt, so as not to cross on a level with increasingly exploited tracks. In this way (with an interval of several decades) one created two viaducts on both sides of the station, which now clearly dominates the surrounding landscape.

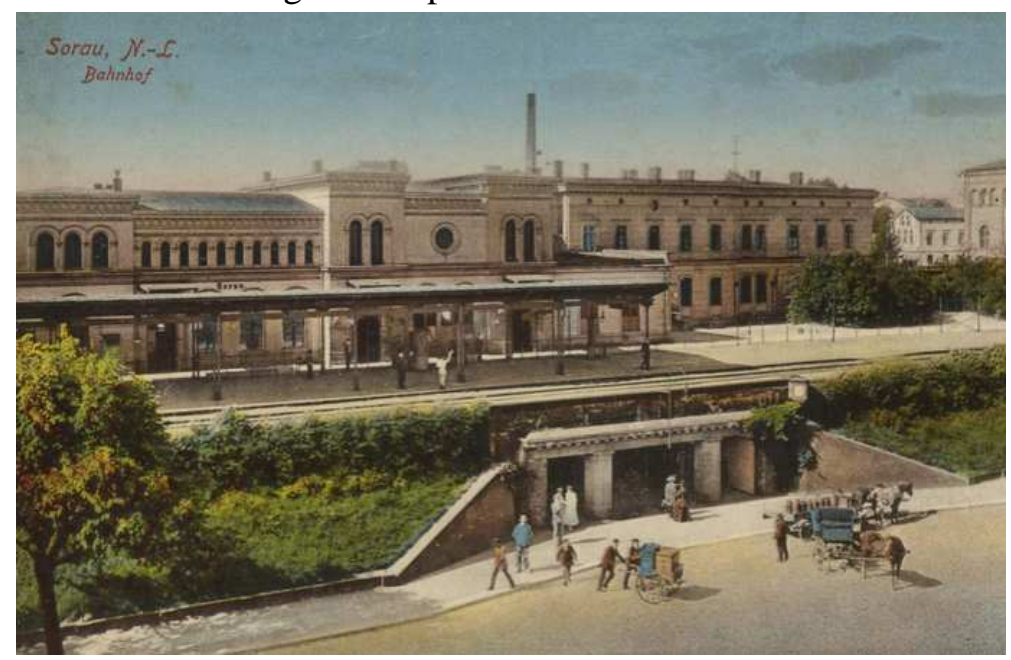

Fig. 2. Railway Station after modernization [www.zary.fotopolska.eu] 
In 1910, the train station was comprehensively modernized, which was then not only the service area, but also a sociable spot of Żary higher class (Fig.2).

The Second World War brought the city a lot of damage. Allied air raids in April 1944 led to the destruction of many objects lying in the city centre, but the station building survived the bombing, remaining in a good technical condition. Only the western part of the station was burnt; as an interesting thing one can add that in its underground one discovered the bunker with strong room.

The importance of railways in the post-war socialist Poland was very large. Żary station was also booming and the late fifties won the title of the best II class stations in Poland. Passenger traffic at the station is so large that the example of "Słowo Żarskie" in 1959 described a way out of the crowded tunnel under the platform to the city as "a way out of hell". At the turn of the fifties and sixties worked there a beer house, unfortunately not equipped with a toilet, whose function began to serve this tunnel [1].

The deplorable condition of the railway infrastructure, as well as the decreasing importance of rail transport in the country contributed to the gradual elimination of other passenger connections, which for the condition of the railway can only have negative consequences.

To this day, the train station in Żary remained one of the largest railway stations in Lubuskie. The complex of railway stations buildings includes, apart from the building of the station ticket office, four covered platforms, underpass, as well as a turntable and now unused building of locomotive shed. Although in recent years the number of railway connections have been strongly reduced operated by the Żary station, one can still drive to many Polish cities (among others: Zielona Góra, Jelenia Góra Wrocław Katowice, Kraków); international connections are also worth mentioning (Berlin, and to December 2014, also Hamburg). Despite this, building is increasingly falling into disrepair, acting as a negative publicity among travellers, giving them a false idea about the state of the whole Żary - which is one of the most dynamic cities in the region. Against the background of a renewed city centre and the constantly enlarging surrounding commercial and residential buildings it is even more annoying view.

\section{CURRENT STATE}

Railway station in Żary is located along Długosz street. Buildings and railway lines lie on the embankment, so the building is well visible from the city centre. The station is brick building, with a flat roof, having two utility floors.

- Usable area: $3183 \mathrm{~m}^{2}$ 
- The cubic capacity: $9244 \mathrm{~m}^{3}$

The main concourse is located in the central part of the building. In the centre are wide single speed stairs leading to the city. In the eastern wing was located the restaurant, while in the western wing Railway offices. On the first floor of the western wing are residential quarters, while in the ground-floor rooms is the control of the trains. The eastern part of the building is currently empty.

Station was built in the classical style. On the facade of the north and the south dominate windows of full and part arches, over which one placed decorative pediments; and one rosette in the central part of the facade. In the central part and on the facade of the eastern wing, windows are placed between pilasters. The floors are separated by a cordon cornice; the highest floor is also topped with a cornice.

In the construction of platforms roofing one used materials characteristic of the heyday of the station - they are rolled structurals connected by rivets and iron casts.

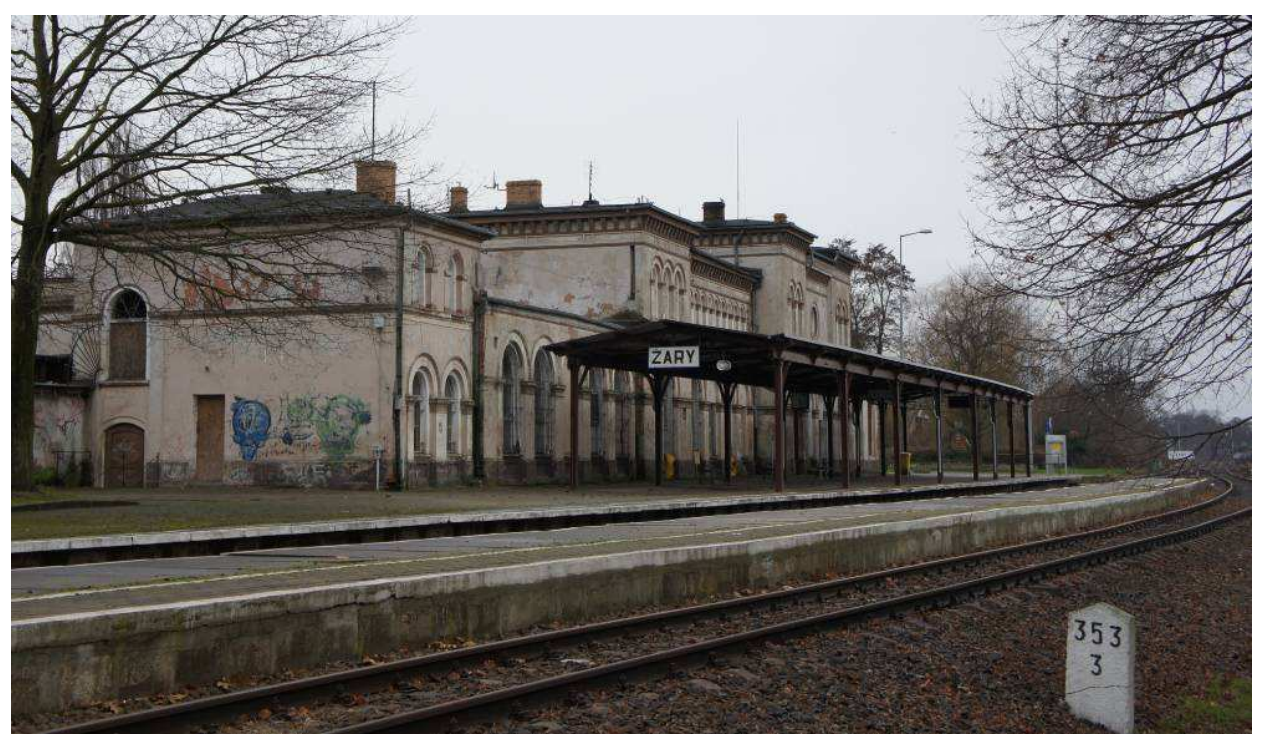

Fig. 3. Train station now - the view from the north

\subsection{The technical condition of the existing facility}

The technical condition of the station and its environment is not satisfactory. The underpass into the station from the Dlugosz street there are numerous oozing, which gave rise to limestone efflorescence on monolithic binders. The roof is supported by cast-iron pillars; above the further (pre-existing) part is Klein's staple ceiling. Exterior walls loaded with embankment ground, as 
a result of erosion caused by water, burst and have local bulges. Original ceramic tiles, which are lined on passage wall, cracked and need repair.

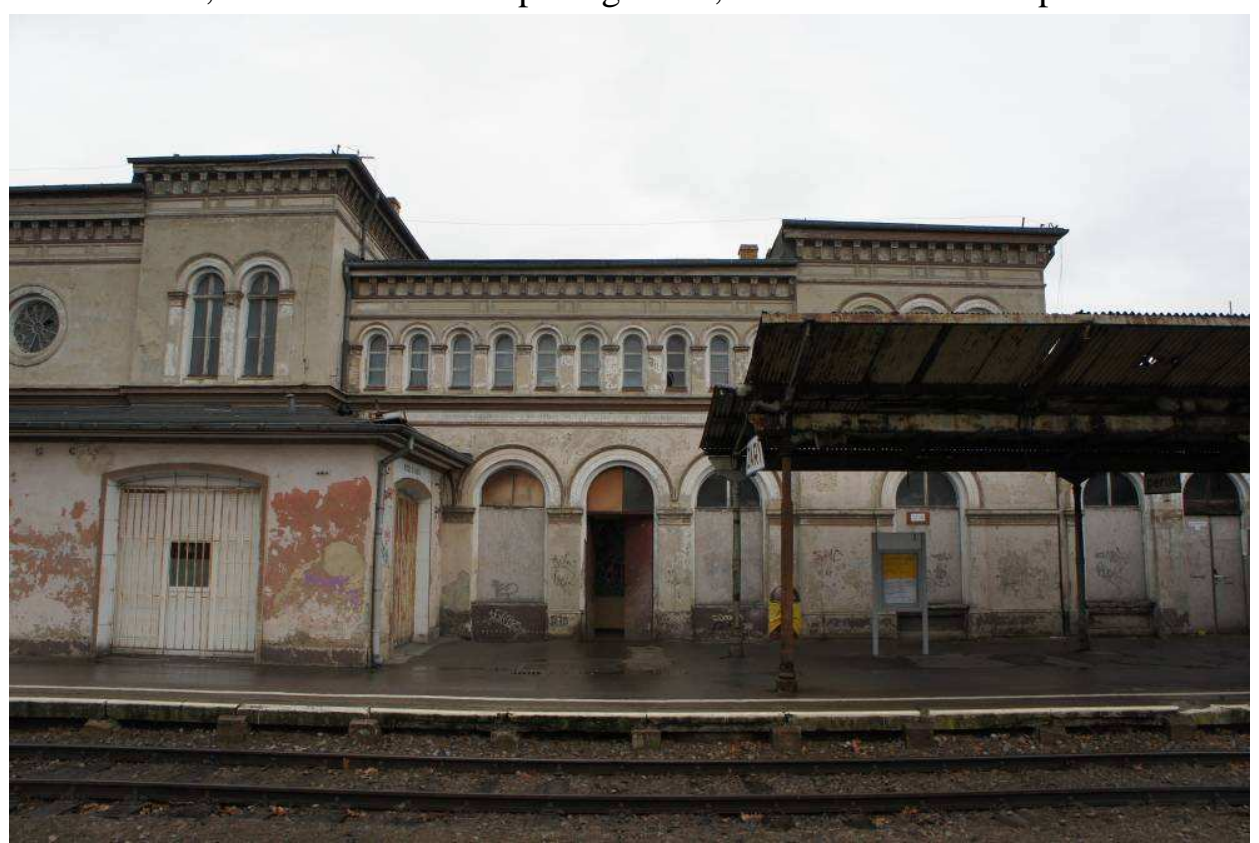

Fig. 4. Train Station now - the view from the south; in the middle of the entrance to the station concourse

The defacing of the technical infrastructure of the building, i. e. an incomplete dehydration, lack of gutters, damaged window sills and window frames, not only affect the disastrous visual state of object, but also lead to its further degradation. The result is a much vaster blistering of plaster, ingrown of vegetation and scouring of the ground around the building. Maintenance works carried out in recent years were superficial and have not been properly chosen. The paint used to repaint the interior pelt. In many places, cracked bitumen revealed the original cobblestones, which is still characterized by high aesthetics. It was a misunderstanding to paint several times the brick wall at the entrance to the underground of the station; raw bricks were much more aesthetically pleasing and required only clearing.

Technical equipment on the station building commemorate all periods of its history, from the glory days, until today. You can see here both original clocks and lanterns and sound equipment of the seventies and the contemporary halogen headlights. Also, each of the three shelters covering platforms looks somewhat different. Columns of first platform shelter are wooden, on the second platform these are fluted cast-iron columns with decorative heads; one 
of the pillars was replaced with a smooth one. The third platform is recently renovated - pillars are the brown painted joists. However, everything is very inconsistent.

The technical condition of the inhabited western part of the building is noticeably better. This fact confirms that for the sake of the proper condition of the building it is most important for the building to be functional.

\section{THE POSSIBILITY OF CHANGES}

Repair work on the building should begin with a thorough rethinking of the function of the train station. Nowadays, travellers' service is definitely not enough in order for this place to bustle. Perhaps it would be possible to provide parts of the premises for service-shopping and dining usage, which would not only attract people, but also guarantee fixed income to the owner.

The building requires protection from further degradation. It is necessary to protect walls against water oozing (repair horizontal and vertical insulation, reconstruction of storm water drainage) and against further cracking. It would be useful to tighten or replace roofing, as well as replace windows and doors. The entire elevation of railway requires renovation, from plaster after the blistering break to filling the gaps in decorative cornices. Function of passenger service enforces ordering of technical systems (lighting, sound system, bulletin board, etc.). On the occasion of a comprehensive renovation it would be worth to think about adapting the building for the needs of the disabled, particularly the construction of an approach ramp or a lift.

Perhaps one could give up some of extensions, such as the one located on the south side. A solid of a rectangular basis disturbs the harmony of the building and does not fit with the rest of the facade.

One would also take care of the area around the station. The demolition of the ruins of former buildings and seeding plants would increase the aesthetic value of the building. Steel railings require straightening and painting. It is also necessary to even surfaces of platforms, and to harmonize the shelters. Applying, for this purpose, modern design could liven up the area around the traditional structure of the station.

\subsection{Trusses of tensegrity type}

Due to the lightweight nature of the structure, platforms sheds could be standardized and rebuilt using tensegrity systems. Trusses of tensegrity type are spatial structural systems consisting respectively of interconnected smaller modules. The composition of each module includes two types of components, which differ in the state of stress. Stretched flexible connectors form a 
continuous network, as opposed to compressed rods. Richard Buckminster Fuller compared tensegrity to the islands (compressing) on the ocean (stretching) [2]. This feature distinguishes tensegrity systems compared to other trusses - the specific arrangement of structural elements makes the rods appear to be suspended in a web of flexible connectors, giving the impression of lightness and airiness. The internal balance is maintained by pre-compressing of ropes.

The variety of tensegrity cells directly affects the shape of the structure resulting from their combinations. In the world are created tensegrity poles (Fig. 5), arches, openwork walls, footbridges, light roof covering, as well as interior furnishings.
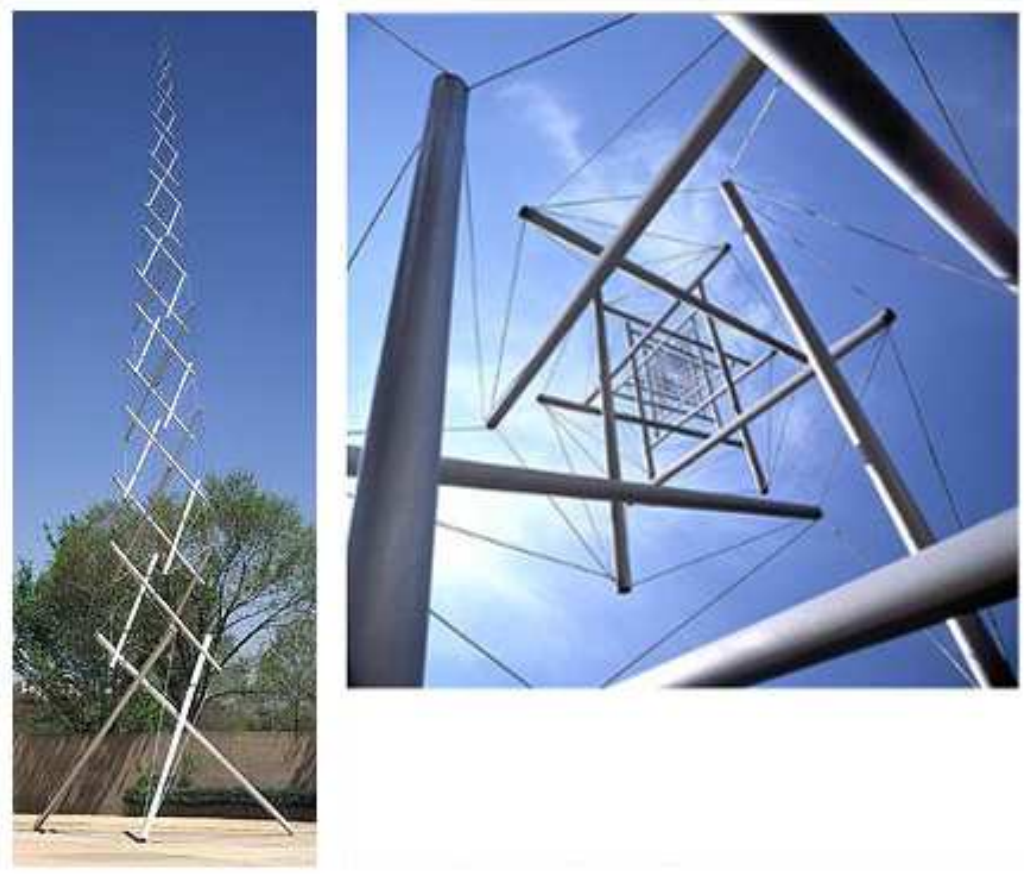

Fig. 5. Example of tensegrity structure: Kenneth Snelson - "Needle Tower" (1968) [www.kennethsnelson.org]

\subsection{New shelters and lighting}

The concept of covering construction of new shelters was based on a simple tensegrity module, consisting of three bars and nine flexible connectors, commonly called Simplex (Fig. 6). It is suggested using steel components. 

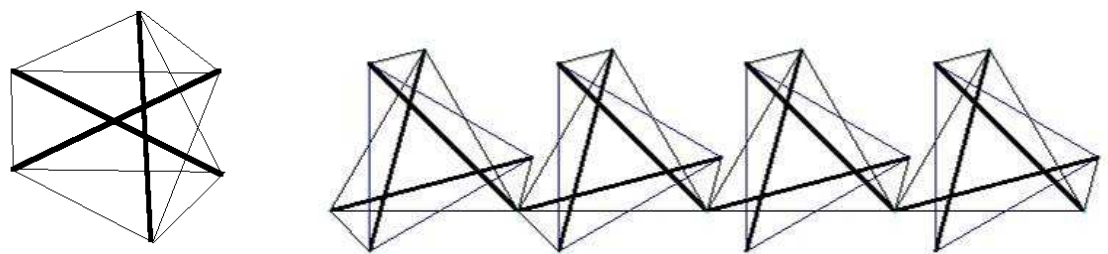

Fig. 6 Simplex module and a structure of covering plan

In order to support structure of covering, it is possible to use existing cast-iron columns.

As the material of covering panels it is recommended to use light permeability material that exemplifies the lightness of the tensegrity structure. It is permissible to use glass plates, but due to the weight of the components it would be better to use a triangular panels of plastics, for example, solid polycarbonate or acrylic glass.

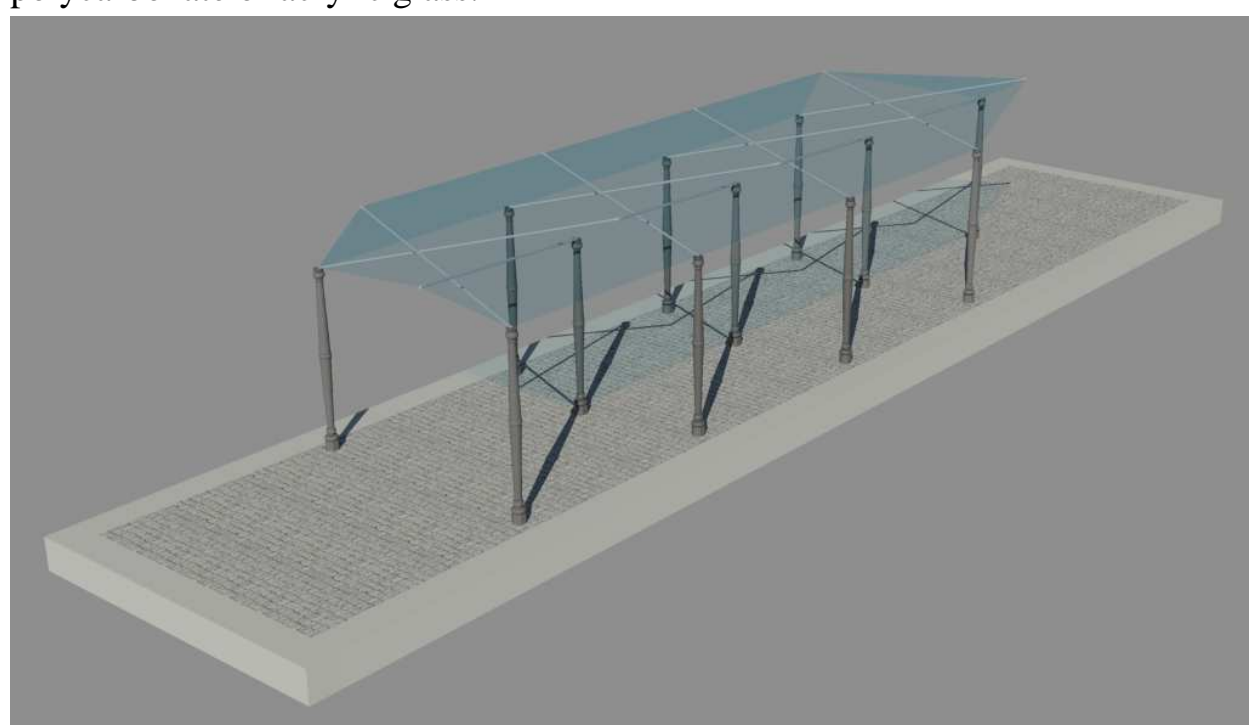

Fig. 7. Visualization of platform shelter

In order to achieve consistency in the appearance of the station there is a need to replace any existing lights, as well as roof covering located above the underground passageway. The effective addition could be tensegrity lamps in front of entering the station from the Długosz street. Such lamps are created by replacing the compressed rods with gas fluorescent luminaire and they are formed in a number of architectural studios throughout the world. It is worth mentioning here the works by Franziska Luther, as well as Michał Bartosik. 


\section{CONCLUSIONS}

Replacement of existing solutions of shelters covering and the underpass at the railway station in Żary with tensegrity modules would have many positive effects. The station building is situated on a hill, but from the city centre it is obstructed by the shelter in the third platform. "Featherweights" of tensegrity design combined with the use of transparent panels as a cover of shelters would reveal a renovated building in all its glory. The undeniable advantage of tensegrity trusses is also their light weight and low consumption of material as compared to other structures. These are non-trivial systems, still little known in our country; they would certainly add modernity to structures, while not obscuring the original facade.

\section{REFERENCES}

1. Dawczyk G.: Z dziejów historii kolei żelaznych na ziemi żarskiej, Żary, Lech Malinowski 2005.

2. Motro R.: Tensegrity. Structural Systems for the Future, Kogan Page Limited 2003.

3. Obiekty industrialne jako zasoby, M. Otto, Institut für Neue Industriekultur INIK e. V., Cottbus 2007.

\section{KONCEPCJA RENOWACJI ŻARSKIEGO DWORCA Z WYKORZYSTANIEM KRATOWNIC TYPU TENSEGRITY}

\section{Streszczenie}

Dworzec kolejowy w Żarach jest jedną z większych tego typu budowli na ziemiach województwa lubuskiego. Dworzec obsługuje połączenia zarówno krajowe (Zielona Góra, Jelenia Góra, Wrocław, Katowice, Kraków), jak i międzynarodowe (Berlin, do niedawna także Hamburg). Mimo to budynek popada w coraz większą ruinę, dając przejezdnym mylne wyobrażenie o stanie całego miasta, będącego przecież jednym $\mathrm{z}$ najbardziej prężnych miast $\mathrm{w}$ regionie. Dlatego celowe wydaje się opracowanie i wykonanie planu odnowienia tego miejsca, tak, aby zachowało swój tradycyjny charakter, a jednocześnie zyskało pewne elementy nowoczesności.

$\mathrm{W}$ pracy przedstawiono historię budynku dworca, a także koncepcję jego odnowienia z zastosowaniem struktur tensegralnych jako elementów konstrukcyjnych przekrycia peronów.

Kratownice typu tensegrity są to konstrukcje cięgnowo - prętowe, w których następuje wzajemna stabilizacja elementów rozciąganych i ściskanych. Charakterystyczne 
„zawieszenie” ściskanych prętów w pajęczynie rozciąganych cięgien sprawia, że konstrukcje te są niezwykle lekkie w odbiorze, a co za tym idzie - pozwalają bez przeszkód dostrzec znajdujące się za nimi obiekty. Ponieważ budynek dworca usytuowany jest na wzniesieniu, zastosowanie ażurowych przekryć znacząco polepszyłoby jego widoczność od strony centrum miasta. Struktury tensegralne dodałyby budowli nowoczesności, nie przesłaniając jednocześnie jej oryginalnej elewacji.

Słowa kluczowe: tensegrity, dworzec, kolejowy, Żary

Editor received the manuscript: 21.01 .2015 